\title{
The Social Status of the Teaching Profession
}

\section{J. Howard Stoutemyer}

To cite this article: J. Howard Stoutemyer (1916) The Social Status of the Teaching Profession, The Pedagogical Seminary, 23:3, 417-440, DOI: 10.1080/08919402.1916.10534457

To link to this article: http://dx.doi.org/10.1080/08919402.1916.10534457

册 Published online: 30 Aug 2012.

Submit your article to this journal 2

III Article views: 5

Q View related articles ๘ 


\title{
THE SOCIAL STATUS OF THE TEACHING PRO- FESSION ${ }^{1}$
}

\author{
By J. Howard Stoutemyer, Lincoln, Nebraska
}

\section{Introduction: The Problem}

Within the last decade there has arisen wide dissatisfaction with the ideals and methods of the schools and school masters. The parent has given vent to his discontent, and the press has given publicity to his out-cry. Civic agencies have initiated inquiries and oftentimes made over their educational organizations. The teachers are also dissatisfied for they are denied economic return commensurate with their expenditure in preparation and service, and are bound fast in the educational machine. The administrative heads, hearing the cries of criticism, have made many changes in their policies, and those most alive to the needs of the hour, call in efficiency experts to diagnose the evils and to propose proper remedies. "All these facts," asserts Professor Suzzallo, "are symptomatic of one underlying truth, that the teaching organization of our public schools is far from satisfactory either to its members or to its patrons, and that we are attempting by hit-and-miss methods to reconstruct the profession of public education. . . . I believe, therefore, that there is no more important question before us than that of the reorganization of the teaching profession." (I9 p. 363.) ${ }^{2}$

In America, teaching does not receive social recognition equivalent to that given many other pursuits in life, which require less preparation, less exaction in health and energy, and which give less than teaching in service and sacrifice in behalf of youth and commonwealth. A part of the blame lies with those teachers who enter the ranks unprepared, greedy for the dollar, who lack forethought and professional interest. Thus we have many epigrammatic statements such as the following: "As the teacher, so is the school," "School

1 Although a considerable body of literature has appeared subsequent to the collection of the above data, yet it is thought that since this is a type study, the general conclusion will remain unchanged, namely, that the social status of the teacher varies directly with the professional training and fitness on the part of the teacher, and adequate return in salary and social esteem on the part of the state.

2 Numbers refer to bibliography at the conclusion of this paper. 
reform means schoolmaster reform." "In order to make our education great, we must make our educators great."

On the other hand, society has neither stimulated the development of these qualities of greatness sufficiently nor recognized them adequately. History records few teachers who have had high praise for their inherent worth, or who have had their services properly recognized and richly rewarded. The usual comment is after this fashion: Emerson thus advised a friend: "Cobble stones, maul rails, pick up stones, plough, make hempen rope, hang yourself at the end of one of them, but don't teach school." When Walter Scott wished a reason for Rueben Butler's occasional error in judgment, he apologetically added: "for the man was a mortal and had been a school master." Longfellow longed to do creative work and loathed the classroom. "I'd rather live awhile on bread and water than to have my life crushed out by teaching." Carlyle says that "Whom the gods wish to make miserable, they first make school teachers of." Bernard Shaw asserts that "Those who can, do; those who cannot, teach."

McAndrews (10) found from his study of the causes of discontent among teachers, that they " are usually commiserated" and are patronizingly looked upon by the average American "who thinks a man would not be a teacher if he could do anything else." " Such of the public as know nothing about teaching regard it as an overpaid sinecure, while the more intelligent members of the community look upon it as an uncertain makeshift, to be taken up only by the man moving on to higher things, or by the woman watching and waiting for her true estate: a husband, a home and family." "The men teachers are pinched with small pay and discouraged by the insecurity of the tenure. The schoolmasters of the cities are slaves to political influence that stunts and paralyzes manliness, while those in the rural communities as to their acts, their speech and their very souls, are the common property of the rural demagogue who wields the power of school trustee." Young men fresh from college take a school to keep the pot boiling while they prepare for something else." "The men in the schools, are not contented for they are leaving all the time for business, for law, for medicine, for preaching, because these occupations bring more respect and are freer from absurd and petty exactions in the matter of mechanical uniformity and routine." For many teaching is still a menial and a hireling occupation, and dismissal, however merited, means a permanent injury. "Teaching is the only business over which the state has monopoly." A lawyer or architect dismissed by the board may open up a shop 
again in the same vicinity without let or hindrance. Thus insecurity of tenure, insufficient remuneration, lack of freedom from political influences and restraints, and the want of social recognition are powerful factors in the present attitude of men towards teaching as a profession.

\section{A. The Bearing of History on the Solution of the PROBLEM}

The solution of our problem lies in understanding what it is and how it came to be what it is. Both of these issues take us back into the history of education and especially the history of the teaching function for materials and method.

When one realizes the exalted place that wisdom held in the thought of the Hebrew people, he can appreciate the importance attached to the office of imparting instruction and the one who instilled wisdom. "A sage is superior to the king of Israel, for if the sage dies, we can hardly find one like him, but if the king died, every Israelite is fit for the position." "He who teaches the son of his friend knowledge will sometime be seated in the heavenly college of wisdom, and he who teaches the son of an ignorant man will have power to nullify even the decrees of the Almighty." "You should revere the teacher even more than your father. The latter brought you into the world; the former indicates the way into the next." The teachers received high esteem for they were closely related to the religious interests of the people "and were largely looked upon as the mouthpieces of Jehovah."

Wherever teaching remained undifferentiated from the priestly function as among the Ancient Egyptians, the Hindoos, or in the Middle Ages, the teaching class was given a similar social esteem which that society had attached to the priestly class. The social status was due to the religious connections rather than to the merits of the teaching class per se.

In the days of Athens' glory, the teacher's status was relatively low and the job of getting right teachers for boys was not always taken seriously. Thus Socrates asked his fellow townsman this memorable question: "Callias, if your two sons were foals or calves, there would be no difficulty in finding some one to put over them; we should hire a trainer of horses or a farmer, probably, who would improve and perfect them in their own proper virtue and excellence; but as they are human beings whom do you think of putting over them?" As Laurie puts it, "the day-school master did not take a high position. Demosthenes taunted his great rival -ith having to help his father clean out the school when he 
was a boy, and evidently regards the work of a primary teacher as a very humble one indeed. 'As a boy,' he says, 'you were reared in abject poverty, waiting on your father in school, grinding the ink, sponging the benches, sweeping the room, doing the duty of a menial rather than that of a freeman's son.' There was no public qualification for the office of school master, and hence chiefly, the low social status. It was the refuge of the distressed. There was a proverbial saying applied to a man who had disappeared: "He is either dead or become a primary schoolmaster." Lucien, long after the palmy days of Athenian education, condemns tyrants sent to the nether world to become beggars or primary schoolmasters. Dionysius the tyrant taught an elementary school at Corinth, and this is mentioned as an illustration of how low a man might fall." (9 p. 277.)

In the earlier Roman periods, the teacher was not held in honor, for they were Greek captives and slaves, and hence the status was low. In the case of Crates of Mallos, who was the first grammar teacher in Rome "It came about in this wise: Having had the misfortune of falling into a sewer, thus breaking his leg, he was thus considered thenceforth good for nothing but to be a teacher." "Nero caused one Paetus Thrasea to put to death for no other reason than that he had a sour cast of countenance, and looked like a school teacher." Horace heaped an immortality of contempt upon Orbilius the most famous teacher of his time. (10, p. 3187.)

The following account from Juvenal illustrates the relative value of the teacher and other household expenditures.

"Just inquire what Chyogonus receives, or Pollio (rhetorical teachers) for teaching these fine gentlemen, and going into all the details of Theodorus' (a famous rhetorician) treatise.

"The baths will cost six hundred sestertia, and the colonnade still more, in which the great man rides whenever it rains. Is he to wait, forsooth, for weather? or bespatter his horses with fresh mud? Nay, far better here! for here the mule's hoof shines unsullied. On the other side must rise a spacious dining-room, supported on stately columns of Numidian marble, and catch the cool sun. However much the house may have cost, he will have besides an artiste who can arrange his table scientifically; another, who can season made dishes. Yet amid all this lavish expenditure two poor sestertia will be ample remuneration for Quintilian. Nothing will cost father less than his son's education.

"Then where did Quintilian get the money for so many, estates?-Quintilian was indeed lucky, but he is a greater rarity than a white crow. But many a man has repented of 
this fruitless and barren employment, as the sad end of Thracymachus proves (pupil of Plato and Isocrates, a teacher at Athens, who meeting with no success hanged himself) and that of Secundus Carrinas (a teacher driven by poverty from Athens and Rome). And you, too, Athens, were witness to the poverty of him on whom you had the heart to bestow nothing save the hemlock that chilled his life blood!" But do your parents, impose severe exaction on him that is to teach your boys; that he be perfect in the rules of grammar for each word read all the histories, know all the authors as well as his own finger ends. . . . Require of him that he be the reverend father of the company, and check every approach to immorality.

It is no light task to keep watch over so many boyish hands, so many twinkling eyes. 'This' says the father, 'be the object of your care - and when the years come around again, "Receive for your pay as much gold as the people demand for the victorious charioteer!" "(The charioteer would receive as much for an hour's drive as the teacher would for an entire year's work. (12, p. 418-9.)

It was only in the latter part of the Roman period where a few municipalities or the government subsidized and thus controlled the schools, that any sort of public system of education arose. "This was accomplished in various ways,-by contributing to school support, paying the salaries of certain teachers or granting them special privileges and distinctions, or offering scholarships to a given number of pupils. Thus Julius Caesar granted the franchise to all foreign teachers already in Rome and offered it to any others who should come; and Augustus, in banishing foreigners from Rome made an exception in favor of teachers. Vespasian, however, established the first real endowment of education by paying salaries of one hundred sestertia $(\$ 4, \infty)$ ) from the Imperial treasury to each Greek rhetorician in Rome. . . . Thruout the second century, this policy was continued, especially by Hadrian; extended by Antonius Pius to the provinces; and enlarged by Marcus Aurelius who, in addition granted a public salary to two rhetoricians and two teachers of philosophy in each of the four schools in Athens. . . . " (7, p. 265.) Besides paying these salaries, Antonius Pius granted exemption to teachers from aedelships, priestships, jury service, municipal and imperial army service, paying of army training masters and the support of soldiers. "The basis on which immunity was granted to teachers was that, in exercising their profession, they were already serving the state; a double service could not be required of them." (20, p. 167.) Constantine showed his interest by promulgating three de- 
crees increasing the privileges of teachers " to the end that those engaged in teaching may with more ease instruct many in the arts and sciences." (20, p. 165.) Gratian induced each of the seventeen capitals to share equally with the government in the payment of salaries of their grammarians and rhetoricians. The status of the successful sophist was high and his advent to a city was the occasion of great rejoicing for he often performed great service in the direction of the civil or foreign policies of the cities. The salaries varied with the time and place but unusual teachers were made the recipients of lavish gifts, as in the case of Herodes who gave Polemo $\$ 45,000$ as a token of his esteem. Hence Walden remarked, "Teaching in the palmy days of sophistry seems to have been a not unprofitable profession." (20, p. I84.)

After the decline of the Empire and after state aid and control were removed, the schools again fell into disrepute and the teacher was given a low social status. In the early Modern Period, teachers served as city clerks, choristers, or other pursuits to eke out a precarious pittance. These teachers were sometimes expelled monks, dissipated wandering scholars, or vagabonds with but a mere smattering of the three R's. In his "Anatomy of Wit" (I579) John Lyly describes the qualifications of the existing school masters. "If among all his servants he shall espy any without wit, or void of honesty, either unthrift, or a wittal, him he sets not as a surveyor and overseer of his manors, but a supervisor of his children's conditions and manners, to him he committeth ye guiding and tuitions of his sons, which is by his proper nature a slave, a knave by condition, a beast in behavior." ( 18, p. 30.) Erasmus complained that "no one is so abandoned, so useless, so insignificant that the common people do not think him fit to conduct a school." Frederick the Second of Prussia appointed his non-commissioned officers as teachers in the lower schools, even tho dissolute, confirmed drunkards, crippled and broken in health, for they needed shelter during the winter months, and such employment kept them out of mischief and saved a pension; besides, their military training would maintain order and discipline in the school room. It had come to such a pass that any detachable member of society without a job for the time being was permitted to assume the obligations of a school master.

The following citations show that early American teachers also occupied a very humble place in the community. As late as I725 the Rev. George Ross of Newcastle, Delaware, wrote that "there are some private schools within my districts which are put very often into the hands of those who are brought into the country and sold for servants. Some 
school masters are hired by the year, by a knot of families who, in their turn, entertain him monthly, and the poor man lives in their homes like one that begged an alms more than like a person in credit and authority. When a ship arrives in the river it is a common expression with those who stand in need of an instructor for their children, Let us go and buy a schoolmaster. The truth is, the office and character of such a person is generally very mean and contemptible here, and it cannot be otherwise 'till the public take the education of children into their mature consideration." (3, p. 58.) Likewise Jonathan Barclay, Rector of Annapolis, Maryland, bears witness in 1678 that there must have been quite a market for teachers for he records that " not a ship arrives with either redemptionists or convicts in which school masters are not regularly advertised for sale, as weavers, tailors or other trades with little other difference that I can hear of except perhaps that the former do not usually fetch as good prices as the latter." (3, p. 65.)

A new England Town Book listed the following duties of the teacher:

" 1 To act as court Messenger. 2 To serve summons. 3 To conduct certain ceremonial services of the church (usually as reader and chorister). 4 To lead the Sunday School. 5 To ring the bell for public worship. 6 To dig graves. 7 To take charge of the school. 8 To take charge of occasional duties." Kilpatrick in "The Dutch Schools of America" cites a number of instances of a similar nature. Thus the early American teacher eked out a precarious existence by performing multifarious duties other than teaching, some of which were in ill-repute, for "teaching was still in the household stage as an industry." The American teacher has since been given legal authority, but no official standing, and his" social status depends more upon his personal qualities and fitness than upon the legal recognition of his calling.

Nearly three-quarters of a century ago, Horace Mann decried the low esteem in which the school master was held and the scarcity of good recruits. "Now I think we have an abundant reason to believe that a sufficient number of persons, bearing from the hand of nature the distinct image and superscription of a school teacher, are born into the world each generation. But the misfortune is, that when they arrive at the years of discretion, and begin to survey the various fields of labor that lie open before them, they find that the noblest of them all, and the one, too, for which they have the greatest predilection, is neither honored by distinction, nor rewarded by emoluments. . . . If they go thru the whole country and question every man, they cannot find a 
single school teacher who has acquired wealth by the longest and most devoted life of labor . . . nor one who has been elected or appointed to fill any distinguished civil station. . . Nor does the social estimation accorded to teachers much surpass the pecuniary value set upon their services. The nature of their calling, debars them almost universally from political honors " and they cannot win fame from business. "No worldly prizes are held up for it and in the present condition of mankind, how few there are who work exclusively for the immortal reward." Those with a mechanical turn of mind go into industry; those with special gifts find their places in medicine, ministry or law. Few engage in it for its own sake; the majority make it subservient to some ulterior end preparatory to some other station in life. "The profession of schoolkeeping has never had an equal chance with its competitors; on the one hand, it has been resorted to by a great number whose only object was to make a little money out of it and then abandon it; and on the other hand, its true disciples, those who might have been and should have been its leaders and priesthood have been lured and seduced away from it by all the more splendid prizes of life." ( I I, p. I83.)

These illustrations show that the professional status of the teacher varies in proportion to state control, professional fitness and remuneration commensurate with that of other professions. In commenting on the position of the teacher in Ancient Education, Lauries states: "It is only when the state takes up education as a national concern that teachers receive proper remuneration, and only when they are professionally trained that they have any status whatsoever." ( 9, p. $277 \mathrm{f}$.) In the present day, the principles herein stated are embodied in the educational systems of France and Prussia, where professional fitness and state direction have resulted in a high social status for the teaching profession. We may now examine the means by which France has developed the social status of her teaching population.

\section{B. The Social. STatis of the Teacher in France}

In France, teaching is recognized as one of the learned professions. He who would teach, even before active preparation begins, understands that it is to be his life work. The strenuous competition for entrance compels the entrant to count well his purposes and to risk his all in the endeavor to get in. When once he has passed into the profession, there is no bidding or encouragement to make it a stepping stone to some other pursuit in life. In looking over the lists of men in the first rank, one is struck with the fact that these 
men are well along in life which means that they have served long in their profession, that they are men of experience and maturity, and have developed some philosophy of life to enable them to wisely guide their pupils.

Then, too, teaching is a closed profession. The entrances are closely guarded so that those who enter must fulfill certain definite requirements in preparation. The teachers in the Primary Schools must have completed these schools, and have taken professional training in their normal school. Since teaching is a permanent profession the exact number of teachers for the following years is computed and only that number may pass the examination for entrance to the normals. The first part of this examination consists in tracing his pedigree, his aptitudes, and attitude towards teaching, and then at the normal there is a week of examinations on subject matter. After completing the three years of training, the teacher is sent out for two years of experience as an apprentice teacher, upon the completion of which he may present himself for another examination to become a permanent teacher.

In the secondary system the competition is even more severe. He must have completed the secondary school, and pass an exacting examination for entrance to the training school. Upon completing his training, he may become a repetiteur in a lycée or a college, or if. he is a doctor of philosophy, he may receive a university appointment. The agrégation examination is the only pass to a professorship in a lycée. The mortality at these examinations is very great, for any one over 27 years of age may compete. Thus men fresh from the university, or men of long experience, or those ofttimes unsuccessful, are all competing for the degree.

In the third place, the French teacher is a state official. His appointment, tenure and payment are all determined by the state; the local authorities have nothing to do with the matter. "When a beginner is seeking a post, he places himself at the disposal of the Minister. If he be agrégé, a post must be given him. If he be only licencié, he may have to wait or take temporarily an inferior post. When a vacancy occurs, the Minister sends a man to fill the post. The master chosen may refuse three posts if they do not suit him. The headmaster must accept the one sent. In order to remedy any inconveniences, every member of the staff has, every November, to state in writing whether he wishes to stay in his present post or to be removed. The headmaster and the Academy Inspector give opinion on each request and may suggest removal." (I 5, p. 27.) The headmaster, if disagreement arises, can prefer charges of inefficiency, immorality, etc., but the office is so securely hedged about that he usually 
lets them go; the most that he does is to delay promotion. While this may lead to insubordination and injustice, it is more than compensated for by the security of the office which enables the teacher to give full attention to his work.

Salary is dependent not on geographical location or political preferment, but on the class. In the secondary system there are six classes and promotion is from the sixth up to the first. To prevent injustice in promotion, the maximum time is 29 years tho a brilliant teacher receiving promotion annually might attain the highest class in 19 years. The rapidity of promotion is largely determined by the amount of funds available for increased salaries. Promotions are made in a definite order, some by seniority and others by selection on the basis of special merit. A certain portion must be of the senior members of that class, but the remainder may be promoted by the inspectors on the recommendation of their proviseurs. Promotion from the first rank in the secondary schools may be to a proviseurship, or a university post, or to be an inspector or rector of an academy.

In the primary system a similar system is in vogue. The import of this provision is at once apparent. A large number come from the peasant class with no other ambition than to return to their own village where family ties and local traditions are binding them. If one remains a teacher, he does not thereby sacrifice his rise in his profession, or increase in salary, for he is a state officer, hired and paid by the state and not by the community, and his promotion and salary depend not on locality or politics but on his rank in his profession. With exception of Paris the same salary attends the same class thruout France, which precludes bidding for position, and the consequent domination of the larger community over the smaller one. In order that a teacher might live befitting his position, in towns above a thousand inhabitants, the teacher has a certain indemnity for his house and maintenance. Not only are good teachers well provided for, but there can be no interference such as exists under local or district control. "The humblest teacher in the most outof-way hamlet, acting as it were as the pioneer of new ideas and new traditions, often in the midst of open indifference or covert hostility feels that he has got a whole ministry behind his back just as the lonely sentinel feels that he has in his rear an army of his friends." (17, Vol. 7, p. 35.)

In France every state official is entitled to a pension after his allotted term is served. The teacher comes in for his share, not as a recipient of charity, but as a right with other state officers. The fund is made up of a fifth of the salary, and one-twelfth of the first salary and each subsequent in- 
crease thereafter. After thirty years of service, the teacher is eligible to his pension; under certain conditions, where injury or loss of health is incurred during service, he is eligible even earlier.

The French educational system has recognized the value of an expert at the head of each division with an advisory council to assist him. Strange as it may seem, the average teacher has much more say as to school policies in the French system, highly centralized tho it is, than is conferred upon the rank and file of teachers in democratic America. The greater number of the national advisory board are his peers elected from his own number, and his representatives sit in the local and departmental councils. In each department a council composed of educational officers and teachers consider the educational problems of that field. Every year, the teacher is expected to write a paper on some educational theme or problem in which he is interested. Such work keeps the teacher alive and out of ruts, and enables the council to keep tab on the pulse of the profession. In practice the Inspectors, both Primary and Secondary, not only give advice freely to teachers, but as freely receive it; indeed, as one author puts it, they usually ask the teacher's advice and seldom act otherwise.

As the teachers in the Lycée have only twelve to sixteen hours per week, they may do tutoring outside, or do extra teaching with additional pay. Every encouragement is given to increase their scholarship, and thus many are working for higher degrees at the university. Those most worthy may receive rewards of merit and honors. For the most efficient in each 300 teachers, there is given a silver medal, for each 120, a bronze medal, and for each 80 there is honorable mention. A limited number of the silver medalists may receive the palms $d^{\prime \prime}$ officer $d^{\prime}$ academie, and after five years this recipient may attain the honor of officer $d^{\prime}$ instructor publique. As teaching is just as much a profession as law or medicine, or the army, the teacher receives public esteem equal to the rank of any public official.

For additional evidence on the solution of our problem we may examine the Prussian teacher's status.

\section{The Status of the Teacher in Prussia}

Prussia was the first of the great nations to realize the significance of a thoroly organized educational system and more than three score years ago took active measures to perfect its teaching profession. Since so many features are of interest to our present American situation, the letter written in I854 by Mr. Kay, an Englishman long familiar with 
the Prussian progress, is quoted at length. "How essential is it then to the moral welfare and therefore to the political greatness of a nation, that the profession of the teacher should be one, inspiring the perfect satisfaction of its members, and commanding the respect of the country!

"The teacher's station in society ought to be an honorable one, or few learned and able men will be found willing to remain long in the profession, even if any such men can be induced to enter it; and it is much better to be without teachers, altogether, than to leave the training of our children to men of narrow minds, unrestrained passions, or meagre intelligence. The Prussian government has fully recognized these truths, and has therefore done all within its power to raise the character and social position of the teachers as much as possible. As these efforts have been heartily seconded by the provincial governments and the people, the result has been most remarkable and satisfactory.

"The first exertions of the government were wholly devoted to the improvement of the intellectual and moral character of the profession, and to the increase of its numbers. They determined to make the name of "teacher" an honor, and in itself a guarantee to every parent of the character and attainments of the man who bore it. To attain this end, they denied all access to the ranks of the profession to any but those who proved themselves worthy of admittance. . . The ranks of the profession are open to all educated and moral men, wherever or however they were educated, but educated and moral they must prove themselves.

"This once attained, the next great effort of the government was directed to the improvement of the social position of the teachers. The government placed them under the immediate protection of the county courts. They also made a law that no teacher who had once been elected, whether by a parochial committee or by trustees or private parents, should be dismissed except by permission of the county magistrate. This protected the teachers from the effects of mere personal prejudice of those in immediate connection with them.

"The teachers of Prussia are men respected by the whole community; men, to whom all classes owe the first rudiments of their education and men in whose welfare and good character and respectability, both the government and the people feel themselves deeply interested. In birth, early recollections, and associations, they are often peasants; but in education and position they are gentlemen in every sense of that term, and acknowledged officers of the county government.

This profession offers a means by which an intelligent peasant may hope to raise himself into the highest rank of society, 
as the expenses of preparing for admission into the profession are borne by the government. But as the number of candidates for admission is consequently always large, the government takes every possible precaution, that only such shall be chosen as are in every respect qualified to reflect honor upon the profession and carry out its objects in the most effective manner, and so well satisfied are the teachers with their position that although their pay is often but poor yet it rarely happens that any one quits his profession to seek another situation. They are contented with their profession, even when it affords only a bare living, as it always confers a station of respectability and honor, in direct communication with the provincial government." (2, pp. 169, I7r.) The reasons which induced the government to render the teachers independent of the local influences were: first, the teachers would lose the feeling of independence and thus fail in the full discharge of their office; and second, the teachers are a learned body and are better qualified to judge of the efficiency of instruction than other people; "but if these persons who have never studied pedagogy could interfere with them, . . . the teachers would often be obliged to pursue some ridiculous, inefficient method, merely to please the whims of persons not experienced in school management, and the enlightenment of the people would thus often be considerably retarded." (2, pp. 174-5.)

The preparation of the elementary teacher, especially for the Volksschulen, while not as severe as for the higher schools, requires the completion of certain prerequisites. He must have completed the lower school and the preparatory school previous to entrance to the normal school. He must furnish with his application for entrance to the preparatory school "a certification of baptism, health and vaccination endorsed by a state recognised physician, and reports on general school work and conduct." ( 8, p. 3I. $) \mathrm{He}$ is examined on his knowledge of religion and school subjects and his ability to use good German. In this school he continues the courses begun in the elementary school. In the normal school, he gets a thoro training in German, a foreign language, either French or English, and mathematics. He receives instruction in psychology, pedagogy, history of his profession and methods, and continuous drill in lesson planning and practice work. When his course is completed, the student takes his first teacher's examination before the government commission which permits only the probation service. During this probation period, appointment is terminable on notice, the only instance in Prussian educational practice. Permanent appointment comes only after the passing of a second 
examination, "which may be passed not less than two and not more than five years after the first" and "aims to discover the ability of the candidate to hold a school appointment." For admission to the examination the report of his district inspector must show his ability to successfully hold a school position. The examination consists of an essay on an educational subject, then the presentation of a lesson to a class on a topic assigned one day in advance; and an oral examination covering the pedagogical studies, and some or all of the subjects of the elementary curriculum. (8, p. 79.) After fulfilling these requirements the candidate is eligible for appointment. "On receiving his appointment, the teacher is ceremoniously introduced to the school and colleagues by the district or local school inspector. Considerable importance is attached to the ceremony of introduction. In no case will its omission be disregarded. It is incompatible with the position of the teacher and the significance of his official position in the school and the community to omit the ceremony." (8, p. 89.) When once appointed, the teacher cannot be dismissed except for grave misconduct and inefficiency. If perchance there is a misfit, the teacher may be transferred to another school. The patrons can do nothing towards securing his dismissal; the inspector can warn and impose a small fine, but it is only the state officials who are qualified to discharge him. "The teacher is a servant of the state and local interference would be regarded as an interference with the rights of the state." (8, p. 90 .) The teaching profession has been safeguarded by the thoro training and examination before the permanent appointment of the candidate, but thereafter the teacher is safeguarded in the free pursuance of the duties of his office.

The prospective teacher in the Higher Schools of Prussia must have completed the course of study in these schools, and the university. Even before leaving the higher schools the prospective teacher is pretty certain that he will enter the teaching profession and also has chosen the particular subjects that he will teach. Neither scholarly distinction nor university degrees will qualify for teaching except as they assist in passing the Staats-Examen, which often requires a year of study beyond the university. This examination intends to test the attainments of the candidate in (I) pedagogy and philosophy, including psychology, logic and ethics, (2) the mastery of the German language and literature, (3) the understanding of the doctrines of his religion, and (4) special proficiency in the subjects which he will teach. The examination in the philosophical subjects is intended to test the breadth of knowledge and a co-ordinated and compre- 
hensive view of the principles underlying educational theories. The examination in religion aims to prevent atheists and socialists from entering the ranks, and it is to be noted that few Jews, however well qualified, find entrance to the profession. The candidate must show a mastery of his native language and literature. The crux of the examination, however, is the subjects to be taught which are arranged in two groups: the language and history group, and the sciencemathematics group. Every candidate is examined in four subjects, the first two being majors, and the second two minors. In order to secure the best combination, the two majors and at least one of the minors must be in the same group. Passing this examination means that he can teach only those subjects in which he has qualified and in the class determined by the grade of his certificate. There are three grades of certificates, which corresponc to the three divisions of the secondary schools, the lower, the middle, and upper. The first grade certificate qualifies for any of the three divisions; the second grade for the two lower; the third only for the lowest division.

Accompanying his application must be his own life history and that of his parents, and his educational credentials must show precisely what he has been doing from the time he entered the higher school up until the examination. He must also make known his election of subjects, his majors and minors, and the grade of examination he desires in each. The written examination consists of essays on topics in philosophy, pedagogy or psychology, and an essay in each of his subjects. He is allowed sixteen weeks, and when he has finished, he must affirm that he has received no assistance other than the authorities listed in his bibliography. After due examination of these documents, the commission sets a day for oral examination which aims to test his ability to express his knowledge of philosophy and special subjects, and his personal fitness for the teaching profession. After passing this examination, he must pursue his special preparation, which consists of a year in the Seminar or training school attached to a higher school, and a year in practice teaching, the Probejahr. In the Seminar he studies the workings of the school, such as hygiene, administration, observation and preparation of lessons, and does some practice teaching under the supervision of the teacher in charge. When the year is up, if the candidate has shown ability in teaching and cooperation with the school, the Director makes a full report to the Provincial School Board, and he is advanced on to the Probejahr. The candidate is assigned to a school where he does six or eight hours' teaching per week, and when it is 
satisfactorily completed, the Director reports to the Board and the candidate's name is inscribed on the list of teachers eligible for appointment.

In state schools the teacher is appointed by the Provincial Collegium while the town councils appoint teachers for the municipal schools subject to the approval of the state officials. As in the case of the elementary teacher, the local patrons cannot in any wise interfere with the teacher's discharge of his office. "Cases of dismissal are exceedingly rare in Germany. Every precaution has been taken to see that a teacher is a fit and proper person for his post before he is appointed. Reports are made on every candidate during his university career, during his training and probation and during his service as Hilfslehrer. If a head master wished for any reason to get rid of an assistant, he would communicate with the governing body immediately above him. An inquiry would be held, and the teacher would appear to defend himself. But if anything should occur to warrant a teacher's dismissal from the profession, he would certainly be given the option of resigning." (I5, p. 260.)

In addition to his salary, which increases according to length of service, the teacher has a substantial rent indemnity. The rent allowance is granted to enable a master to reside in a dwelling befitting his status as! a high civil servant or municipal magistrate. The amount granted varies according to the estimated annual cost of such residence in the town where he is employed. After ten years of service, Oberlehrer in state and municipal schools are entitled to a pension in case of being incapacitated for work in school. In Prussia, "years of service" include the year of military service, the seminar year, and year of probation and the time above four years as Hilfslehrer, and a $\$ 200$ rent allowance is added to the last salary. The pension allowances are: after ten years of service, $25 \%$ of last salary; after 25 years' service, $50 \%$ of last: salary; after 40 years' service, $75 \%$ of last salary. Widows may receive $40 \%$ of the pension which the husband was receiving or was entitled to receive at his death. Each child receives one-fifth of the allowance of the mother, but in no case should the total exceed the pension which the husband and father would have received.

Teachers in the state or municipal schools have the standing of civil servants who have completed a definite amount of work in training, who have been appointed by state officers, and who follow a definite career with titles to express the duties and positions filled. Russell states: "Special privileges are granted to teachers in accordance with their rank. All state officials of Prussia are carefully classified and the 
gradation is punctiliously observed on all state occasions. The ordinary higher-school teachers belong to the fifth class; directors and professors of twelve years' service belong to the fourth class; and occasionally the crown honors a very old man who is distinguished as a teacher and director with the privilege of the third class and the title of Geheimer Regierungs-Rat. Provincial school inspectors and ministerial counselors, being administrative officers, are ranked by themselves in higher classes." ( $16, p .376$.$) The assertion is made$ in the book on "Conditions of Service of Teachers" that the only profession in Prussia that can be definitely compared with that of the teacher is that of the "Richter," which combines the functions of magistrate and judge. In academic training the judge has a little longer probation and training, and is a little older when he enters upon his duties, and therefore receives a slightly larger remuneration, but in point of advancement the two are similar.

The high qualifications required of the members of the teaching profession in Prussia, in physical and moral fitness, in breadth of academic scholarship and professional training, prevents the unfit from entering the ranks; but when once within the profession, the teacher's course is attractive, with security of tenure, freedom of teaching, a comfortable living wage, a pension when disabled and the high social status of a government official. Prussia has made the school the key to unlock the gates of national welfare and fortune, and, consequently, esteems the schoolmaster for his great national service.

\section{The Status of the American Teacher}

From the foregoing illustrations, we may infer that, when there is no high academic and professional qualification required for admission into the ranks of the teaching body, the abundant supply of unfit teachers reduces the standard of teaching efficiency to the lowest terms, and hence gives a very humble social status to the teacher. When the state requires a relatively high qualification in professional preparedness, and gives in return security of tenure and a sufficiency of remuneration, a relatively high social status is a natural consequent. Here then we may see the source of the lack of social repute of the American teacher and the cause of his dissatisfaction. In the first place the teacher is not professionally trained, and inefficient tests of teaching ability grant the right to teach; then, too, there is a lack of maturity and experience, frequent shifts and a lack of state support and control.

From recent reports of the Commissioner of Educa- 
tion, one may find such statements as these: the supply of trained teachers is entirely inadequate to meet the demand, and thousands of places must be filled by half-trained and untrained teachers. In general, only one in five positions have available a trained graduate, and in many districts not more than one in ten. In some regions the average education is not more than the seventh grade, and in a number of the states a large proportion of the teachers have less than a four-year high school course. For instance, West Virginia has $43.6 \%$ in this class and less than $16 \%$ normal or college graduates; Tennessee has $63 \%$ with less than a four-year high school course and only $12 \%$ normal or college graduates. Since the term of service is four years or less in the rural schools, there are needed annually 92,000 teachers, of whom less than one per cent have had definite training for the work they are undertaking. These beginners are intelligent, resourceful and conscientious, and their only real fault is that they lack educational preparation, teaching and life experience, all of which most of them will get in time by experimenting on their pupils, the most part of whom, however, do not survive the experiment. The American educational policy has been to permit the novice to begin with the least possible training and experience, whereas the Continental policy has required high qualifications.

The recent awakening on the rural life problems has developed several score of training schools for rural teachers and many more which offer courses leading to the understanding of farm problems. Only as the administrative and supervising machinery of the rural schools develops, removing control from men unacquainted with the fundamental principles of rural school management, and biased by local politics, can there arise a professional teaching attitude in our rural schools. When a mode of salaries is installed which rewards ability and experience instead of locality or politics, then and only then can the smaller communities hope to have as efficient teachers as the larger city systems. Since our American notion of democracy and competition fosters the bidding for efficient teachers by administrators who can pay more, village and rural communities become practice fields and dumping grounds for the cities. Salaries increase according to size of city rather than according to preparation or experience. Equal pay for equal work in whatever vale or hamlet would go a long, long way towards the prevention of the frequent shifts in the teaching body.

The lack of permanency permeates our whole educational system. This is true even in our state departments. In many states the superintendent is nothing more than a political 
officer and changes as rapidly as the wolf-catcher. Oftentimes the make-up of the members of the State board of education are ex-officio, or appointed on political grounds, or for short periods of tenure. The city boards are in a constant flux, and certainly the smaller units are even more unstable. The superintendents of our cities have a median tenure of three years or less. The tenure ot teachers in the secondary schools of the North Central Association is two years or less. The tenure in the rural schools is two years or less of 140 days each, or less than a calendar year. It is probable that 75 per cent of the rural teachers and 50 per cent of the town teachers shift their positions annually. The wonder grows that our educational system is as effective as it is, when there is so little continuity in office, and hence no chance to mature adequate plans and policies and certainly no opportunity to perfect them.

In contrast to continental practice, our teaching body is immature in life and teaching experience. In Prussia, few teachers are prepared for a permanent post before they are 25 years of age and not infrequently before 30 . In his study of rural school teachers in the United States, Foght found that in seven states the average age of the teachers when beginning was 18 years or less, and the average for the entire country was 19.2 years when beginning. The average of the rural school teacher is 26 years, which means that the rural teacher is still immature in life experience. In the study of Danish schools (6) Foght found that 50 per cent of the women teachers are 30 years old or older, and 50 per cent of the men are 40 years old or older. This means that their teachers have had time to develop their own philosophy of life and have had sufficient experience with life's problems to wisely direct their pupils.

The proverbial American attitude has been that anybody could do anything at any time without any definite preparation to do that thing. We have not taken education seriously as a national concern. We expend as much on clothes as on education, twice as much for tobacco and chewing gum as for education, and many times more for drink and crime than for education. In a number of states more is expended for the care of the wards of the state than for the education of free independent citizens. "Whatever complaints we may make of the dominance of the dollar in American life, the incontestible fact exists that the public that pays out threefourths of its taxes for protection of life and property, willingly, pays out one-fourth for public education grudgingly." Germany, France, Denmark, Japan,-all have seen their wonderful national possibilities realized thru an ably directed and 
supported school system with a professionally trained and stable teaching profession.

The next significant move must be the cessation of easy filtration into the teaching body, and the stopping of the leakage from the ranks. It must be made worth while to get in, and less worth while to get out. Our mode of certification of teachers must in some wise test the ability and preparation of the teacher. With the exception of California the largest part of the certification is by the passage of some kind of examination. The usual type tests the ability to cram rather than the traits of the efficient teacher. France and Prussia embody both the training and examination of the candidate. After the candidate has completed his training he comes up for his examination which covers the native fitness, training, and the ability to control and teach a class in an assigned subject before an expert commission. Certification on the fitness of the teacher in mind and body for the teacher's office, and the ability to control and instruct a class in a schoolroom is worth infinitely more than a cram test of books dealing with the subject of class instruction and management.

There is a need of revision in the appointment and promotion of teachers. The old district system with its board of local directors with no other qualification for choosing teachers than their local interest in education stands at the extreme of inefficiency and shortsightedness. The opposite tendency is towards a civil service regime which removes appointment from politics, local prejudice or personal favor, and recognizes training and merit as prerequisites. Custom, and in a few states, legal enactments, require the annual election of the teacher which involves a tremendous and unnecessary expenditure of energy both by teacher and the board. Such a procedure is detrimental to the best interests of the schools, and drives the most efficient teachers from the profession, for teachers alone of all those employed in pursuits requiring special training and skill, must annually run the chance of dismissal. On the other hand, without adequate selection of the fit at the entrance to the profession, it would not be possible to make tenure permanent. Even civil service rules must provide rules for some means of eliminating the unfit, and of humanely disposing of those professionally dead. It would be better to adopt a common sense business plan of continuance in office during efficient service. Cubberley asserts that "the whole burden now rests on the teacher when the whole burden of dismissal should rest on the board. The teacher's continuance in office ought to be assumed unless the board is willing to take the responsibility of notifying the teacher in writing, with reasons, that the board desires to 
terminate the contract at the close of any school year. . . . Such a change would shift the burden of continuance of employment from the teacher to the board where it should rest, and would practically give life tenure to every competent teacher, at the same time leaving the board free to discontinue the services of incompetent, unprogressive teachers. . . . Such a change in the school laws of the various states would practically solve the difficulties now met with all over the country, without inflicting life tenure on any community. Such a proposal would naturally meet with the opposition of many of the school boards, because it would compel them to justify their actions more fully than they now need to do and it probably would be opposed by some teachers now living under life tenure because it would demand keeping alive and efficient as a condition of retention." (I3, Vol. 5, p. 56.)

When the various attachments to the teacher's salary in France or Prussia are taken into account, it appears that the American elementary school teacher is underpaid during the period of service, and unpaid after the period of service has passed. Ayres states that " the wages received by school teachers constitute a measure of two things: first, the quality of the ability of the teacher; second, the value the community puts upon the teacher's service. The fact that teacher's wages are lower than those paid any other sort of service means that as a nation we place a low valuation on the teacher's work." (I, p. 23.) Münsterberg asserts that "there was never before a nation that gave the education of the young into the hands of the lowest bidder." Since three-fourths of those engaged in teaching are women who can underbid men, Münsterberg warns us that we are placing a premium on the celibate spirit which Rome has done for ages, by hiring the female celibate and discriminating against the wife and mother. The most capable men are rapidly being driven out of the profession either by lack of remuneration, or else by greater attractions in other lines of business. Since teachers' salaries have increased but slightly in comparison with the rise in the cost of living, and since society demands much from teachers in the way of standards of living, appearances, and public duties, the compensation in salary is but a precarious pittance.

Even when teachers remain in the profession, their period of service is short in comparison with many other fields of labor. The public demands young and vigorous teachers and those past prime have difficulty in securing locations equal to their ability. "Teachers wear out young and are relegated to the scrap heap" at a time when other professional groups are entering their most productive periods. Retention in of- 
fice during competency and good behavior does not solve all of the problems of educational efficiency. Retention beyond the period of physical fitness and teaching capacity, " however much it appears to be the desert of the poorly paid and unpensioned teacher, can only be viewed as a public calamity when the defenseless children are taken into account." It is practically impossible for teachers partially incapacitated, or growing less efficient, to find positions without the loss of selfrespect or the infliction of an immeasurable harm upon growing children. The teaching profession should have some humane and satisfactory methods of retiring those incapable of rendering the required grade of work. The teachers who are active and efficient should have the sense of security and the opportunity for an undivided service in their profession. The stability of the profession will largely depend on the development of a state and an inter-state system of pensions. This will tend to attract a more efficient class of teachers and will be a greater incentive to remain in the service and grow in professional capacity. The retirement allowances and pensions are relatively new innovations in this country, yet according to Prosser, twenty-three states have more or less legislation bearing upon pensions for teachers, and nineteen cities support various types of ventures for superannuated teachers. "More than thirty-five per cent of our population enjoy the educational benefits to be derived from such funds, while thirty per cent of the entire teaching force of the public schools of the United States have opportunity to protect themselves against one or more of the five great risks of life." ( 14, p. 5.)

In addition to the foregoing factors for the attainment of a better social status for the teacher, there should be developed a more closely co-ordinated unity of thought and purpose within the profession itself. This could be accomplished in part by the development of a higher general educational attitude in the teaching population and in the public opinion of the country as a whole. But to be effective and permanent, this sentiment should be embodied in an organization or institution. As Suzzallo has outlined the policy, there should be local units of great flexibility; these local units should constitute a state organization which should elect representatives to a national organization. This national organization should have an advisory committee and a paid secretary to guide the activities of the organization. In the annual conferences, there would be considered the general problems of public education, of matters of common policy and comity between states, of investigating, and disseminating professional information for the greater efficiency of educational practice. 
This organization should also foster the growth of a professional spirit and pride in the individual members, and should enlarge the conception of significance of their mission.

\section{E. Summary}

In fine, the more important means then for the improvement of the social status of the teacher are: proper state certification of teachers and an interstate standard, based upon professional fitness and ability to teach; tenure during efficiency and good behavior, and promotion thru merit in teaching and development in the profession; compensation for the work done in whatever locality commensurate with the expense in time and energy in preparation, the rise in the cost of living, and in proportion to the service rendered to the state; a state and inter-state system of pensions in which the teacher and state, or states, conjointly contribute to the funds for the protection of the old age and incapacity of the teacher. In addition to these, public opinion should be educated to adequately evaluate the services of the teacher and render a corresponding social status; then, too, the individual members of the teaching population should develop permanent professional interests and attitudes, and a vital relationship with the fundamental problems of our civilization.

\section{BibLIOGRAPHY}

I. Ayres, L. P. A Comparative Study of Public School Systems in Forty-eight States. New York, Russell Sage Foundation, 1912, pp. 32.

2. Barnard, Henry. National Education in Europe. New York, Charles $H$. Norton, 1854, pp. 890 .

3. Dexter, E. G. History of Education in the United States. New York, Macmillan Co., 1904, pp. 656.

4. Farrington, F. E. French Secondary Schools. New York, Longmans, Green \& Co., 19ro, pp. xii, 450.

5. Fogte, H. W. Efficiency and Preparation of Rural School Teachers. United States Bureau of Education Bullettn 1914, No. 49.

6. Fogrt, H. W. Rural Denmark and Its Schools. New York, Macmillan Co., I915, pp. 355 .

7. Graves, F. P. History of Education. Before the Middle Ages. New York, Macmillan Co., rgog, pp. xiv, 304.

8. KANDEl, I. L. The Training of Elementary Teachers in Germany. New York, Teachers College, 1910, pp. vii, 137.

9. LAURIE, S. S. Pre-Christian Education. London, Longmans, Green \& Co., 1895, pp. viii, 436 .

10. McANDrews, WM. The Present Status of the Professions-Public School Teaching. World's Work, March, 1903, Vol. 5, pp. $3187-93$.

II. MaNN, Horace. Reports on Education. Vol. 4.

12. Monroe, Paul. Source-book for Greek and Roman Period. New York, Macmillan Co., 1905, pp. 771. 
I3. Monroe, Paul. Cyclopedia of Education. New York, Macmillan Co., 5 Vols.

I4. Prosser, C. A. The Teacher and Old Age. Boston, Houghton, Mifflin Co., 1913, pp. xi, 140.

15. Report of Conditions of Service of Teachers. London, I910.

16. Russell, J. E. German Higher Schools. Longmans, Green \& Co., I907, pp. 489.

17. SADLER, M. E. English Reports on Educational Subjects. Vol. 7.

18. Sandiford, Peter. Training of Teachers in England and Wales. New York, Teachers College, I9ro, p. I65.

19. Suzzallo, Henry. Reorganization of the Teaching Profession. National Education Association, 1913, pp. 362-375.

20. Walden, J. W. H. Universities of Ancient Athens. New York, Scribners \& Sons, 1909, pp. xiv, 367 . 